\title{
Finding long protein products of alternatively spliced genes
}

\author{
Neil Moore', Jerzy W Jaromczyk ${ }^{1 *}$, Christopher L Schardl ${ }^{2}$ \\ From 11th Annual UT-ORNL-KBRIN Bioinformatics Summit 2012 \\ Louisville, KY, USA. 30 March - 1 April 2012
}

\section{Background}

In eukaryotes, pre-mRNA molecules undergo splicing, which is the removal of sequences called introns to produce mature mRNA transcripts whose open reading frames (ORFs) may then be translated to proteins. Often this splicing step may be performed in many ways - a situation known as alternative splicing $[1,2]$ that can be described by structures such as splice graphs [3]. Alternative splicings, even those that differ only slightly, may result in proteins with substantially different biological properties [4,5].

\section{Materials and methods}

We have developed an algorithm for finding the longest ORFs of alternatively spliced transcripts described by splice graphs. Our algorithm executes in time linear in the size of the splice graph (and therefore optimal), determining the splicings that result in an open reading frame encoding a maximal-length protein for that gene. We show how our algorithm may be used to help identify biologically interesting protein products from RNA-seq data.

\section{References}

1. Sammeth $M$, Foissac $S$, Guigó R: A general definition and nomenclature for alternative splicing events. PLOS Computational Biology 2008, 4(8).

2. Sugnet $C W$, Kent WJ, Ares M, Haussler D: Transcriptome and genome conservation of alternative splicing events in humans and mice. In Pacific Symposium on Biocomputing Altman RB, Dunker AK, Hunter $L$, Jung TA, Klein TE, World Scientific 2004, 66-77.

3. Heber S, Alekseyev M, Sze SH, Tang H, Pevzner PA: Splicing graphs and EST assembly problem. Bioinformatics 2002, 18(suppl 1):S181-S188.

4. Harrow J, Nagy A, Reymond A, Alioto T, Patthy L, Antonarakis S, Guigo R: Identifying protein-coding genes in genomic sequences. Genome Biology 2009, 10:201.

5. Xing Y, Yu T, Wu YN, Roy M, Kim J, Lee C: An expectation-maximization algorithm for probabilistic reconstructions of full-length isoforms from splice graphs. Nucleic Acids Research 2006, 34(10):3150-3160.

6. Moore N, Jaromczyk JW: Finding a longest open reading frame of an alternatively spliced gene. Proc. IEEE Intl Conf. on Bioinformatics and Biomedicine 2011 (BIBM 2011) Workshops, Workshop on Integrative Data Analysis in Systems Biology (IDASB) 2011, 215-222.

doi:10.1186/1471-2105-13-S12-A12

Cite this article as: Moore et al.: Finding long protein products of alternatively spliced genes. BMC Bioinformatics 2012 13(Suppl 12):A12.

\section{Acknowledgements}

This work was partially supported by NIGMS Grant 1R01GM086888-01, Kentucky NSF-EPSCoR Grant 0814194, NSF Grant EF-0523661, and USDA-NRA Grant 2005-35319-16141.

An earlier version of this work [6] was presented at presented at the Workshop on Integrative Data Analysis in Systems Biology in 2011.

\section{Author details}

'Department of Computer Science, University of Kentucky, Lexington, KY 40506, USA. ²Department of Plant Pathology, University of Kentucky, Lexington, KY 40506, USA.

Published: 31 July 2012

\footnotetext{
* Correspondence: jurek@cs.uky.edu

${ }^{1}$ Department of Computer Science, University of Kentucky, Lexington, KY 40506, USA

Full list of author information is available at the end of the article
}

Submit your next manuscript to BioMed Central and take full advantage of:

- Convenient online submission

- Thorough peer review

- No space constraints or color figure charges

- Immediate publication on acceptance

- Inclusion in PubMed, CAS, Scopus and Google Scholar

- Research which is freely available for redistribution
C Biomed Central

(c) 2012 Moore et al; licensee BioMed Central Ltd. This is an Open Access article distributed under the terms of the Creative Commons Attribution License (http://creativecommons.org/licenses/by/2.0), which permits unrestricted use, distribution, and reproduction in any medium, provided the original work is properly cited. 